\title{
sciendo
}

\section{Some considerations concerning the shares}

\author{
Ana-Maria LUPULESCU \\ Bucharest University of Economic Studies, Bucharest, Romania \\ ana.lupulescu@drept.ase.ro, anamarialupulescu@yahoo.com
}

\begin{abstract}
The registered capital of the company by shares is divided into fractions known as shares, which, unlike the parts of interests or social parts, represent negotiable instruments, presenting first of all the advantage of being negotiable and freely transferable, subject to limitations that could be introduced by the associates by the constitutive act. Therefore, in exchange for the contributions made to registered capital of the company by shares, the associates receive a number of shares corresponding to the value of these contributions, which represents a certain fraction of its registered capital.

Taking into account the negotiable nature of the shares, the quality of shareholder derives and is more related to the quality of owner of shares, dissociating itself from that of signatory of the company's constitutive act, obliged, inter alia, to make contributions, the latter quality being relevant only at the moment of incorporation of the company. Actually, during the existence of the company, the quality of owner of shares, and therefore of shareholder, can change significantly and uninterruptedly, depending on the operations performed with these titles, causing appropriate changes in the shareholder structure of the company.
\end{abstract}

Keywords: company by shares, legal nature of shares, particularities of shares, classification of shares.

\section{Introduction}

The company by shares is the company of capital par excellence, since this legal form of company is set up and functions only in consideration of the contributions made by the associates, who are liable for the social obligations within the limit of these contributions, so that the person of the associates or the trust among them is of no importance. In exchange for their contributions to the setting up of the company, the shareholders receive negotiable instruments, which can be freely traded (Lupulescu, 2019).

Therefore, the registered capital of the company by shares is divided into fractions known as shares, which, unlike the parts of interests or social parts represent negotiable instruments, having primarily the advantage of being negotiable and freely transferable, subject to limitations that could be introduced by the associates by the constitutive act. Therefore, in exchange for the contributions made to the setting up of the company by shares, the associates receive a number of shares corresponding to the value of these contributions, which represents a certain fraction of its registered capital.

\section{Legal nature and particularities of the shares}

In terms of its legal nature, the share is an intangible movable thing. This opinion was expressed in the jurisprudence, in the context of the previous regulation contained in the Civil Code of 1864 (for instance, the Bucharest Court of Appeal, the 5th Civil Section, civil judgment no. 15 from January 17, 2012, published on the portal of Romanian courts of law (http://portal.just.ro/2/Lists/ Jurisprudenta/DispForm.aspx?ID=1304). We emphasize that under the current regulation, the legislator has renounced to regulate separately in the Civil Code the category of movable goods by determination of the law, as well as to provide the rights it assimilates to movable goods. In this sense, art. 474 par. 1 of the Civil Code of 1864 provided "Are movable by the determination 
of the law, the obligations and shares having as object amounts due or securities, the shares or the interests in finance, trade or industrial companies, even when the capital of these companies consists in immovable goods", thus expressly including the shares in this category of movable goods. Nevertheless, art. 542 par. 2 of the Civil Code provides in a general manner that all patrimonial rights, except for real rights over immovable goods, referred to in par. 1 of the same article, have the legal regime of movable goods. Therefore, even under the current regulation, shares are movable goods, being securities that incorporate debt rights.

Equally, according to art. 101 par. 1 of Law no. 31/1990 republished, the shares are indivisible. Thus, representing a fraction of the registered capital, neither the share, namely the title, nor the rights it incorporates can in principle be divided. For these reasons, to the extent that the share becomes the subject of a joint ownership right belonging to several persons, the coowners will exercise their rights deriving from the title, including the right to vote in the general assembly, through a single representative. Regarding the quality of the single representative, in the silence of the law, the French doctrine has emphasized that he/she is freely appointed by the co-owners, and may be chosen from among them, but also a third party (Le Cannu \& Dondero, 2014). We consider that this solution can also be applied in our law, in the context of the similar regulation contained in the Romanian law. Despite this way of exercising the rights deriving from the share, organized by law mainly for practical reasons, as well as the fact that they are the holders of only an ideal quota of the ownership right over a share, the co-owners have, each of them, the quality of shareholder, reason for which they are jointly and severally liable for the payment of the subscribed contributions (art. 102 par. 4 of Law no. 31/1990 republished).

At the same time, the shares are represented by negotiable instruments. As such, the shares are in principle freely transferable, which is an essential feature that distinguishes them from parts of interest or social parts. This characteristic derives from the legal nature of companies of capital, in which the intuituu personae element is absent, reason for which in principle any shareholder can acquire this quality and, subsequently, transfer freely the titles he/she owns, without the consent of others. Moreover, from a formal point of view, the transfer of shares is simpler, the law does not impose in this case the formalities that accompany the assignment of parts of interest or social parts, such as the conclusion of an assignment contract. On the contrary, the transfer of shares takes the form of substituting the transferor for the transferee in the register of shareholders, by means of a declaration signed by both parties. If the shares are issued in materialized form, the same statement will be mentioned on the title (art. 98 paragraph 1 of Law no. 31/1990 republished). However, if the shares are admitted to trading on a regulated market, their transfer will have to be made in compliance with the rules applicable on that market.

Although in principle the shares are freely transferred, still there are exceptions, namely the possibility of imposing valid restrictions on this transfer. In certain cases, in order to protect some general interests, the legislator itself establishes such restrictions, temporary and related to the incidence of a certain situation, such as the one provided by art. 81 of Law no. 85/2014 on insolvency prevention and insolvency proceedings. Thus, for the purposes of the abovementioned text of the law, following the opening of insolvency proceedings against the company issuing the shares, until the date of confirmation of a reorganization plan, the shares are suspended from trading on the regulated market on which they are traded.

However, most restrictions on the transfer of shares are conventional, agreed by the shareholders at the setting up of the company or during its functioning and inserted in the constitutive act. Moreover, the legislator recognizes in principle the possibility to establish, by 
the will of the shareholders, such restrictions, since art. 8 letter f2 of Law no. 31/1990 republished includes them among the compulsory mentions of the constitutive act of the company by shares. However, in order to be effective, such restrictions must be described in an explicit and detailed manner in the company's constitutive act, in particular regarding the conditions under which they may be exercised, which are of strict interpretation and application.

In this regard, it has been emphasized in the jurisprudence that the provision in the constitutive act of a pre-emption right related to the transfer of shares in favour of the other shareholders constitutes such a restriction, as it conditions the right of disposal, as regards the acquirer of the shares (for instance, Bucharest Court of Appeal, 5th Commercial Section, judgment no. 74 from February 6, 2009, published on the portal of Romanian courts of law (http://portal.just.ro/2/Lists/Jurisprudenta/DispForm.aspx?ID=393). Such a clause, although not expressly provided for by law, is valid, insofar as it is clear and explicit in terms of the conditions for exercising the right of pre-emption, especially taking into account the legal recognition of the possibility of imposing conventional restrictions on the transfer of shares. It can be provided in the constitutive act from the moment of its conclusion, or it may be inserted by way of its amendment, in accordance with the law. On the other hand, it does not represent a valid restriction on the transfer of shares, but a real inalienability clause, the clause according to which the transfer of shares to other shareholders or to third parties can be made only based on the decision of the general assembly of shareholders, especially since the criteria according to which this body of the company is entitled to refuse to authorize the transfer are not determined. This solution has been emphasized in the jurisprudence (for instance, Bucharest Court of Appeal, 5th Commercial Department, judgment no.74 from February 6, 2009, mentioned above).

Also regarding the transfer of shares, giving expression to the institutional approach regarding the company by shares, as well as the autonomy of the subject of law that it represents, the law conceives in principle the acquisition of a certain number of shares by the company itself, for a limited period of time, but subjects this operation to very strict conditions, as they appear from the provisions of art. 1031-104 of Law no. 31/1990 republished. In principle, only fully paid-up shares may be acquired by the company itself, in a proportion that may not exceed $10 \%$ of the registered capital, and for the period in which they are owned by the company, the main rights deriving from these titles, respectively the right to vote and the right to dividends may not be exercised (art. 105 of Law no. 31/1990 republished).

The shares have a nominal value, which expresses the correspondence that exists between the value of the contributions made by the shareholders and the value of the registered capital of the company. Thus, the nominal value of a share is the result of the mathematical operation of dividing the value of the registered capital by the number of shares issued by the company. In this respect, art. 8 letter f of Law no. 31/1990 republished imposes the compulsory provision, in the constitutive act, of the nominal value of the shares, while art. 93 par. 1 of the same normative act sets a minimum limit of lei 0.1 per share, probably in order to avoid the excessive division of the company's registered capital and the unjustified increase of the potential number of shareholders. At the same time, within the meaning of the law, the shares issued by the same company have an equal nominal value, because they incorporate, in principle, equal rights (art. 94 paragraph 1 of the Law no. 31/1990 republished). However, the legislator allows the coexistence, within a company by shares, of categories of shares that grant to their owners different rights, which will have the same nominal value, regardless of the category to which they belong (art. 95 par. 2 of Law no. 31/1990 republished). 
On the other hand, in that regard, the similar provision contained in the French Commercial Code, concerning the equal nominal value of shares, has been abrogated, on the ground that the existence of different categories of shares granting different rights to their owners may justify their issuance with distinct nominal values between categories, but which remain equal within the same category. Moreover, even before the abrogation of this legal provision, in French doctrine and jurisprudence it was considered that it is not imperative, meaning that one can derogate from the rule it contains, because only the equality between shares belonging to the same category must be ensured within the company (Ripert \& Roblot, 2002). However, this conclusion cannot be extrapolated to the rule established by the Romanian law, taking into account the imperative wording of the provisions of art. 94 par. 1 and art. 95 par. 2 of Law no. 31/1990 republished. Moreover, the French law in its current form, namely art. 228-8 of the French Commercial Code, provides for the mention of the nominal value of the shares in the constitutive act as a possibility, and not as an obligation, as it is stipulated by Romanian law. However, it has been emphasised correctly in the French literature (Ripert \& Roblot, 2002) that, in the event that the associates choose not to mention the nominal value of the shares in the constitutive act, it does not mean the absence of such a value, which still can be determined by the same mathematical operation, because the share is a fraction of the registered capital. However, certain legal systems, such as American, Canadian or Belgian law, allow for the issuance of shares with no nominal value (Ripert \& Roblot, 2002).

\section{Classification of shares}

Concerning the types of shares, traditionally, depending on how the owner is identified and the shares are transmitted, a distinction was made, also provided by the law, between registered shares, i.e. those that identify their owner, and bearer shares, in which case the possession of the shares determines their owner, respectively the person who can exercise the rights incorporated in the title. The anonymity of the bearer shares was considered to generate significant security risks, and for this reason the possibility of issuing this category of shares was eliminated by the Romanian legislator through Law no. 129/2019 for preventing and combating money laundering and terrorist financing, as well as for amending and supplementing some normative acts (Published in the Official Gazette, Part I no. 589 of July 18, 2019), which transposes into our law a several European directives adopted in this field, especially Directive (EU) 2015/849 of the European Parliament and of the Council of May, 202015 on the prevention of the use of the financial system for the purpose of money laundering or terrorist financing, amending Regulation (EU) No. 648/2012 of the European Parliament and of the Council and repealing Directive 2005/60/EC of the European Parliament and of the Council and Commission Directive 2006/70/EC, published in the Official Journal of the European Union, L series, no. 141 of June 5, 2015 and Council Directive (EU) 2016/2.258 of December 6, 2016 amending Directive 2011/16/EU on the access of tax authorities to information on combating money laundering, published in the Official Journal of the European Union, L series, no. 342 of December 16, 2016.

Therefore, under the current regulation, the registered capital of companies by shares can only be divided into registered shares, which identify their owner. Moreover, within 18 months from the date of entering into force of Law no. 129/2019, the companies issuing bearer shares have the obligation to convert them into registered shares, by amending the constitutive act in accordance with the law, under the sanction of the dissolution of the company, which may be requested in the court of law by any interested person, including the National Office of the Register of Trade, at the expiration of the deadline provided by the law. This ground of 
dissolution is also remediable, in the sense that the company will be able to proceed to the conversion of the shares until the moment when substantive conclusions are sustained before the court of law (art. 61 paragraph 7 of Law no. 129/2019).

Concerning the registered shares, the ownership right over them results either from the statements made on the title or from those mentioned in the register of shareholders of the issuing company. They can be issued both in material form, on paper, in which case the title must bear all the specifications provided by art. 93 par. 2-4 of Law no. 31/1990 republished, including the identification elements of the owner, and in dematerialized form, by sole registration in the account of the owner, hypothesis in which his rights are not materialized in a title. In the latter situation, respectively if the company issues shares in dematerialized form, it is also obliged to send to the shareholders, at their request or by its own initiative, shareholder certificates, which reproduce in principle the specifications provided by law in case of shares issued in material form (art. 97 of Law no. 31/1990 republished). However, the shareholder certificate is only indicative and its issue does not change the form of the shares, as it does not incorporate the rights conferred by shares to their owner.

In connection with this traditional division of shares into registered and bearer shares, we emphasize that this is maintained by French law (art. L 228-1 of the French Commercial Code), because unlike the Romanian legislator this legal system has chosen other methods for transposing European directives and thus eliminating the risks arising from the anonymity of bearer shares. As a consequence, under French law, all shares, whether registered or bearer shares, are issued in dematerialized form by registration in the account of the shareholder (Cozian et al., 2013). As such, concerning the bearer shares, their material form has also disappeared, so that the traditional way of transferring ownership over them, respectively the tradition - the material handing over of titles to the new owner, no longer finds its applicability. However, the anonymity of bearer shares has been maintained, at least as far as the issuing company is concerned, as in principle shareholder accounts are managed by independent intermediaries. For these reasons, it has been emphasized in the French literature that bearer shares have in fact changed their legal nature, so that their denomination is now meaningless, and therefore it would be preferable to speak of anonymous titles (Roblot, 1984).

At the same time, as we have already mentioned, the shares issued by a company by shares may incorporate the same rights. However, the law allows the creation, at the setting up of the company or during its existence, under certain conditions, a distinct category of shares, which grant to their owners different rights, namely preferential shares with priority dividend without voting rights (art. 95 et seq. of Law no. 31/1990 republished). Therefore, depending on the absence or, on the contrary, the existence of certain preferential rights attached to some of them, the shares are classified into ordinary shares, which incorporate equal rights, and preferential shares, which grant to their owners certain advantages not generated by ordinary shares. However, in order to counterbalance the special rights offered by the title, the preferential shares do not have the right to vote. Within the meaning of art. 95 par. 2 of Law no. 31/1990 republished, the company by shares may issue preferential shares for a value not exceeding one quarter of the registered capital. As it results from the provisions of the law, the preferential shares confer to their owners a pecuniary advantage, respectively a priority dividend, taken over the distributable yearly profit before any other distribution. Furthermore, the owner of the preferential shares enjoys all the rights deriving from the quality of shareholder, except for the right to vote in the general assemblies. Therefore, the owners of these shares participate to a lesser extent in the actual conduct of the company's business, in the sense that, although they 
retain the right to be present within general assemblies, they are deprived of the opportunity to participate in collective decision-making, lacking the right to vote.

We also emphasize that most legal systems recognize the possibility of issuing preferential shares, which guarantee different benefits to their owners. Moreover, priority dividend shares are also provided for in the French legal system, although they have been introduced more recently (Ripert \& Roblot, 2002), but also in the English one (Bourne, 2011).

\section{Conclusions}

Taking into account the negotiable nature of the shares, the quality of shareholder derives from and is more related to the quality of owner of shares, dissociating itself from that of party to the company's constitutive act, obliged, inter alia, to make contributions, the latter quality being relevant only at the moment of incorporation of the company. Actually, during the existence of the company, the quality of owner of shares, and therefore of shareholder, can change significantly and uninterruptedly, depending on the operations performed with these instruments, causing appropriate changes in the shareholder structure of the company.

Although in principle most legal systems recognize the essentially transferable nature of shares, they also provide for the possibility of imposing restrictions from this point of view, in principle of a conventional nature. Thus, for example, under English law, the articles of incorporation of companies may impose different categories of restrictions on the transfer of shares, including restrictions under the form of recognition of an absolute freedom of directors to refuse to register such transfers, with the sole reservation derived from the condition to act in this manner in good faith. However, restrictions on the transfer of shares may not apply to listed companies, their titles being freely negotiable without any circumstances or obstacles (Bourne, 2011).

As far as the classification of shares is concerned, unlike Romanian law, which in principle conceives preferential shares only in the form of those with a priority dividend, without the right to vote, different European legal systems recognize other categories, which grant to the owners different advantages, not necessarily related to the right to dividends. From this perspective, under English law companies by shares may decide to divide their registered capital into different categories of shares, having complete freedom in this respect, provided, however, that this possibility of issuing preferential shares is recognized in a general manner in their articles of incorporation. At the same time, according to English law, the preferential shares can be with priority dividend, but also of other categories, such as convertible shares, respectively those that can be converted into ordinary shares either on a certain date, or at the request of the owner or even the company (Dignam \& Lowry, 2012), redeemable shares, which can be redeemed at the request of the company or the shareholder, as well as shares that benefit from additional voting rights or even a veto right in relation to ordinary shares (Bourne, 2011). Equally, French law allows the creation of preferential shares with or without the right to vote, incorporating special rights of any kind, such as shares with a double vote, shares with an increased dividend as a loyalty bonus granted to shareholders who have maintained this quality for at least two years etc. (Ripert \& Roblot, 2002). 


\section{References}

Bourne, N. (2011). Bourne on Company Law (5 $5^{\text {th }}$ ed.), London, Routledge.

Cozian, M., Viandier, A., \& Deboissy, F. (2013). Droit des sociétés [Company Law] (26 ${ }^{\text {th }}$ ed.), Paris, LexisNexis.

Dignam, A., \& Lowry, J. (2012). Company Law (7th ed.), Oxford, Oxford University Press.

Le Cannu, P., \& Dondero, B. (2014). Droit des sociétés [Company Law] (6 ${ }^{\text {th }}$ ed.), Paris, LGDJ.

Lupulescu, A.M. (2019). Some specific aspects concerning the company by shares, Tribuna Juridica / Juridical Tribune, 9 (1), 79-89.

Ripert, G., \& Roblot, R. (2002). Traité de droit commercial. Les sociétés commerciales [Commercial Law. The Commercial Companies], Paris, LGDJ.

Roblot, R. (1984). La dématérialisation des valeurs mobilières [The dematerialization of securities], Bull. ANSA, 185. 